\title{
Phenotypic expression of double heterozygosity for BRCA1 and BRCA2 germline mutations
}

\author{
B Leegte, A H van der Hout, A M Deffenbaugh, M K Bakker, I M Mulder, A ten Berge, E P Leenders, \\ J Wesseling, J de Hullu, N Hoogerbrugge, M J L Ligtenberg, A Ardern-Jones, E Bancroft, \\ A Salmon, J Barwell, R Eeles, J C Oosterwijk
}

$M$ utations in two major cancer susceptibility genes, $B R C A 1$ and BRCA2, predispose to early onset breast and ovarian cancer. Since 1994, genetic testing for germline mutations in these genes has been carried out in many countries in both diagnostic and research settings. Mutation analysis is usually done on the basis of a (family) history of breast or ovarian cancer-for example, (very) early age of onset, multiple affected close relatives, multiple tumours in one patient, and breast cancer in men. ${ }^{1-3}$ Ethnic background may also play a role in decisions about DNA testing, as in some populations founder BRCA1 or BRCA2 mutations are known to occur at relatively high prevalence (for example, 185delAG and 5382insC in BRCAl and 6174delT in BRCA2 in Ashkenazi Jews ${ }^{4}$ ).

In recent years several families have been described in which more than one BRCA mutation segregated, predominantly involving Ashkenazi Jewish founder mutations. These reports describe families that harbour two pathogenic $B R C A 1$ mutations, ${ }^{5}$ one BRCAl and one BRCA2 mutation, ${ }^{6-17}$ or even three pathogenic mutations in BRCA genes. ${ }^{18}$ Some of these families were uncovered because the index case appeared to carry two (founder) mutations, and only rarely was cosegregation of two different mutations suspected beforehand on the basis of the family history. This has led to the recommendation that one should always test for all three founder mutations in individuals of known Jewish ancestry. ${ }^{19}$ However, DH has also been reported without prior knowledge of Jewish ancestry. ${ }^{10} 1213161720$

In this paper we present four new cases with mutations in both BRCAI and BRCA2 and review and update the 30 cases reported in the literature, in order to investigate the phenotypic consequences of double heterozygosity (DH)that is, the presence of pathogenic mutations in both BRCAl and $B R C A 2$ in one individual.

\section{CASE REPORTS}

The first proband had papillary serous ovarian cystadenocarcinoma stage IIb at age 40 and unilateral infiltrative ductal breast carcinoma at age 45 . She was referred to the clinical genetics department because she was considering prophylactic contralateral mastectomy if she harboured a genetic predisposition. She has 10 siblings and a positive maternal history (fig 1). Her mother had had ovarian serous cystadenocarcinoma at the age of 67 . One maternal aunt had bilateral breast cancer at 60 years of age, and a maternal cousin died of breast cancer at the age of 43. The father of the proband died of a brain tumour at age 52, but this was too long ago to retrieve the medical data. There was no history of breast or ovarian cancer in the paternal family, and no known Ashkenazi Jewish ancestry. Based on her medical history and family history, BRCA1 and BRCA2 testing was carried out.

\section{Key points}

- Detection of double heterozygosity (DH) for BRCA1 and BRCA2 mutations has implications for genetic counselling and possibly for clinical management. We review 34 women with $\mathrm{DH}$ to assess phenotypic expression.

- In the diagnostic setting DH occurs in $0.09-0.36 \%$ of index cases - that is, in $0.22-0.87 \%$ of proven $B R C A$ mutation carriers, rising to $1.8 \%$ in Ashkenazi Jews. At least one of the detected mutations is usually a founder mutation, mainly 185 delAG and 5382insC in BRCA 1 and 6174delT in BRCA2.

- The phenotypic expression in DH varied from unilateral breast cancer at age 26 to cancer-free survival at age 70. Twenty four cases had a total of 32 primary cancers; the mean age at first breast cancer was 40.8 years (range 26 to 70 ), and for ovarian cancer, 45.7 years (range 36 to 57). The age related incidence for first cancer was $84 \%$ (38\% to $99 \%$ ) at age 70 , and median cancer-free survival was 45 years (range 33 to 57). The genotype 5382insC/6174delT seemed to confer the highest cancer risk.

- In non-Ashkenazi populations DH is rare. Compared with carriers of a single BRCA1 or BRCA2 mutation, $\mathrm{DH}$ does not seem to lead to a more severe phenotype. The presence of a second mutation has important consequences for genetic counselling. We suggest that index cases should always be tested for all known founder mutations, that co-segregation in BRCA positive families must if possible be confirmed, and that mutation analysis should be extended where there is a tentative phenocopy with a positive history on both sides, in order to avoid missing a second BRCA mutation.

Protein truncation testing of exon 11 of $B R C A 1$ and exon 10 and 11 of BRCA2 indicated a truncating mutation in BRCA1. Sequencing demonstrated a two base pair deletion (2804delAA) in BRCA1, a known Dutch founder mutation. ${ }^{21}$ Because the sample was used to validate the denaturating gradient gel electrophoresis (DGGE) analysis we were developing for BRCAI and BRCA2, ${ }^{22}$ additional testing was carried out even though the causative mutation had already been found. Unexpectedly, this revealed a second mutation in

Abbreviations: $\mathrm{DH}$, double heterozygosity; $\mathrm{LOH}$, loss of heterozygosity 


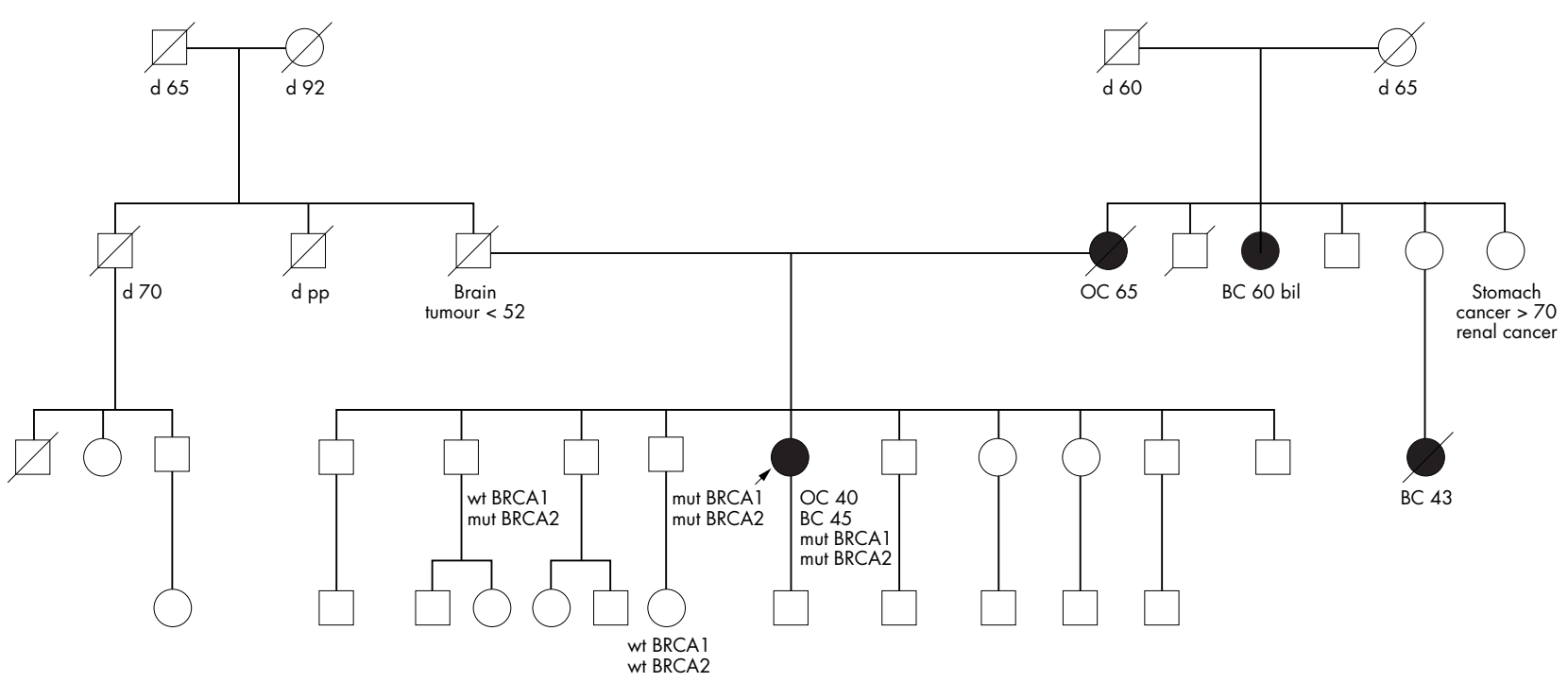

Figure 1 Anonymised pedigree of case 1. The proband is indicated by an arrow. Squares, male; circles, female. BC, breast cancer; $d$, deceased; OC, ovarian cancer; PP, postpartum.

BRCA2: $3715 \mathrm{delG}$, a novel mutation that leads to a stop codon at position 1167.

Subsequently, these mutations were detected in brothers of our proband, confirming that both are inherited and neither is a de novo mutation. Maternal and paternal family members declined DNA testing, and ovarian tumour specimens of the patient's mother were no longer available. We were therefore unable to determine whether one mutation came from either parent or whether both were inherited from the mother.

The woman was counselled about the presence of the two distinct genetic predispositions and informed that her risk of a second breast cancer could be around $60 \%$ (the figure for women with only one mutation) or even higher. She subsequently underwent a prophylactic mastectomy (with no malignancy on pathological examination) and is free of disease at the age of 51 years.

The second Dutch case attended the hereditary cancer clinic at age 50 years. She was treated for unilateral ductal breast cancer with positive axillary lymph nodes at age 28 . She was referred because of her daughter, who was 32 years old at that time. Family history was not informative. She is the only child of her parents' relationship, and they both died young from unknown causes. There were maternal half brothers and sisters but she had no contact with them. DNA analysis showed that she had the Dutch founder mutation 2804delAA in BRCA1, and a single base pair deletion (4677delA) in BRCA2. She was without second cancer at age 49, when she had a prophylactic bilateral salpingooophorectomy. There were no (pre-)malignant lesions on pathological examination. A contralateral prophylactic mastectomy is planned.

Both cases from the United Kingdom had Jewish founder mutations, and were ascertained through diagnosis in a clinical genetic setting.

Case 3 is a healthy woman aged 40, who had a prophylactic bilateral mastectomy at 35 years, and a prophylactic bilateral salpingo-oophorectomy at 36 years. Both the mutations 185delAG and 6174delT were previously unknown in the family. The BRCAl mutation was subsequently found in a maternal second cousin of the proband. The mother of case 3 had bilateral breast cancer at 37 and 39 years, respectively; a maternal aunt had ovarian cancer at 42 years, the maternal grandmother had breast cancer at 51 years, and five maternal great aunts had breast cancer (one bilateral). One second cousin had ovarian cancer at 43 years, breast cancer at 58 , and subsequently fallopian tube cancer. In the paternal family no breast or ovarian cancer is known. The maternal side of the family only harbours the BRCAl mutation and no one has been tested from the paternal side of the family.

Case 4 was affected by left sided invasive lobular carcinoma at age 51. She had no prophylactic surgery and had no further cancer or recurrence to date at age 68 . She has a BRCA1 5382insC mutation and a BRCA2 6174delT mutation. Her unaffected brother's daughter had breast cancer at 34 years and harbours the BRCAI 5382insC mutation. Her unaffected daughter, who is 40 years old, has the 6174delT mutation. The proband's mother had no cancer at age 71, but a maternal aunt had breast cancer aged 70 years. One maternal cousin had bowel cancer in his 50s and 60s. The proband's father did not have cancer, but a paternal cousin had a cancer of unknown origin at 57 years. Unfortunately segregation analysis could not be carried out in this family.

\section{REVIEW OF CASES WITH DOUBLE HETEROZYGOSITY}

Data on various cases with DH described by Frank et al ${ }^{23}$ were updated and extended with respect to mutations and phenotypic expression. We found an additional 22 cases with DH from a total of 13 reported families. ${ }^{7} 10-1315162024$ The report by Caldes et al is the only one involving a missense mutation, which initially raised doubts about its pathogenicity. We decided to include this family, based on the literature on this mutation which is at an evolutionarily highly conserved residue in a functional motif of the BRCAl protein (BRCT repeat); the missense change has a high chemical difference score, the mutation is absent in appropriate control populations, and the mutant alleles are always found to be retained in the tumours. ${ }^{25-28}$ It is striking, however, that the phenotypic expression in all these cases (from one family) turned out to be less severe than in the other DH cases. One case report on a woman with breast cancer before the age of 35 is not included, because presumed DH was based on tumour sample analysis only-that is, without constitutional DNA analysis or family history. ${ }^{29}$ In the series of Frank et $a^{23}$ there were nine women who were diagnosed with DH. In one of these the clinical data were missing, so she was excluded from analysis. In the series of 
Table 1 Review of reported cases with BRCA1/BRCA2 double heterozygosity

\begin{tabular}{|c|c|c|c|c|c|c|}
\hline \multirow{2}{*}{ No } & \multirow{2}{*}{$\begin{array}{l}\text { DH (index) } \text { cases }^{*} \\
\text { OC } 40 \text { and BC } 45 \text { (51) }\end{array}$} & \multicolumn{2}{|c|}{ Mutationsł } & \multirow{2}{*}{$\begin{array}{l}\text { FH: } \\
\text { maternal/ } \\
\text { paternal§ }\end{array}$} & \multirow{2}{*}{$\begin{array}{l}\text { Inheritance confirmed? } \\
\text { Both mutations familial, maternal/paternal } \\
\text { origin undetermined }\end{array}$} & \multirow{2}{*}{$\begin{array}{l}\text { Reference } \\
\text { This report (AZG) }\end{array}$} \\
\hline & & $\begin{array}{l}\text { BRCA1 } \\
\text { BRCA2 }\end{array}$ & $\begin{array}{l}\text { 2804delAA } \\
\text { 3715delG }\end{array}$ & & & \\
\hline 2 & BC 28 (49) & $\begin{array}{l}\text { BRCA1 } \\
\text { BRCA2 }\end{array}$ & $\begin{array}{l}\text { 2804delAA } \\
\text { 4677delA }\end{array}$ & $\mathrm{Neg} / \mathrm{Neg}$ & No information available & This report (UMCN) \\
\hline 3 & Healthy 40 & $\begin{array}{l}\text { BRCA1 } \\
\text { BRCA2 }\end{array}$ & $\begin{array}{l}\text { 185delAG } \\
\text { 6174delT }\end{array}$ & Pos/?? & $\begin{array}{l}\text { Two maternal cousins } 185 \mathrm{del} \mid \mathrm{AG}, 6174 \mathrm{delT} \\
\text { probably paternal }\end{array}$ & This report (UK) \\
\hline 4 & BC 51 (68) & $\begin{array}{l}\text { BRCA1 } \\
\text { BRCA2 }\end{array}$ & $\begin{array}{l}\text { 5382insC } \\
\text { 6174delT }\end{array}$ & Pos/?? & $\begin{array}{l}\text { Maternal niece 5382insC, origin } 6174 \text { delT } \\
\text { unknown }\end{array}$ & This report (UK) \\
\hline 5 & $B C<39$ & $\begin{array}{l}\text { BRCA1 } \\
\text { BRCA2 }\end{array}$ & $\begin{array}{l}\text { 187delAG } \\
\text { 6174delT }\end{array}$ & $\mathrm{Neg} / \mathrm{Neg}$ & No information available & This report/Frank et al ${ }^{23}$ \\
\hline 6 & BC 40 & $\begin{array}{l}\text { BRCA1 } \\
\text { BRCA2 }\end{array}$ & $\begin{array}{l}\text { 5385insC } \\
\text { 6174delT }\end{array}$ & $? ? / ? ?$ & No information available & This report/Frank et al ${ }^{23}$ \\
\hline 7 & BC 41 & $\begin{array}{l}\text { BRCA1 } \\
\text { BRCA2 }\end{array}$ & $\begin{array}{l}\text { 187delAG } \\
\text { 6174delT }\end{array}$ & $\begin{array}{l}\text { Pos } \\
\text { Neg }\end{array}$ & No information available & This report/Frank et al ${ }^{23}$ \\
\hline 8 & Bilat BC 34 & $\begin{array}{l}\text { BRCA1 } \\
\text { BRCA2 }\end{array}$ & $\begin{array}{l}\text { 187delAG } \\
\text { 6174delT }\end{array}$ & $\begin{array}{l}\text { Pos } \\
\text { Pos }\end{array}$ & No information available & This report/Frank et al ${ }^{23}$ \\
\hline 9 & Bilat BC 33 (49) & $\begin{array}{l}\text { BRCA1 } \\
\text { BRCA2 }\end{array}$ & $\begin{array}{l}\text { 5385delAG } \\
\text { 6174delT }\end{array}$ & $\begin{array}{l}? ? \\
? ?\end{array}$ & No information available & This report/Frank et al ${ }^{23}$ \\
\hline 10 & Bilat BC 55 (56) & $\begin{array}{l}\text { BRCA1 } \\
\text { BRCA2 }\end{array}$ & $\begin{array}{l}\text { 187delAG } \\
\text { 6174delT }\end{array}$ & $\begin{array}{l}\text { Pos } \\
\text { Neg }\end{array}$ & No information available & This report/Frank et al ${ }^{23}$ \\
\hline 11 & Healthy 61 & $\begin{array}{l}\text { BRCA1 } \\
\text { BRCA2 }\end{array}$ & $\begin{array}{l}\text { 5385insC } \\
\text { 6174delT }\end{array}$ & $\begin{array}{l}\text { Pos } \\
\text { Neg }\end{array}$ & No information available & This report/Frank et al ${ }^{23}$ \\
\hline 12 & Healthy 66 & $\begin{array}{l}\text { BRCA1 } \\
\text { BRCA2 }\end{array}$ & $\begin{array}{l}\text { 187delAG } \\
\text { 6174delT }\end{array}$ & $\begin{array}{l}\text { Pos } \\
\text { Neg }\end{array}$ & No information available & This report/Frank et al ${ }^{23}$ \\
\hline 13 & $\mathrm{BC} 48$ and $\mathrm{OC} 50$ & $\begin{array}{l}\text { BRCA1 } \\
\text { BRCA2 }\end{array}$ & $\begin{array}{l}\text { 185delAG } \\
\text { 6174delT }\end{array}$ & $\begin{array}{l}\text { Pos } \\
? ?\end{array}$ & No information available & Ramus et al ${ }^{10}$ \\
\hline $\begin{array}{l}14 \\
15\end{array}$ & $\begin{array}{l}\text { Index BC } 38 \\
\text { Mother OC } 50+\end{array}$ & $\begin{array}{l}\text { BRCA1 } \\
\text { BRCA2 }\end{array}$ & $\begin{array}{l}\text { 185delAG } \\
\text { 6174delT }\end{array}$ & $\begin{array}{l}\text { Pos } \\
\text { Pos }\end{array}$ & $\begin{array}{l}\text { Father had neither mutation, mother } \\
\text { assumed carrier of both mutations }\end{array}$ & Friedman et $\mathrm{al}^{11}$ (pat No 1) \\
\hline 16 & OC 57 (62) & $\begin{array}{l}\text { BRCA1 } \\
\text { BRCA2 }\end{array}$ & $\begin{array}{l}\text { 185delAG } \\
\text { 6174delT }\end{array}$ & $\begin{array}{l}\text { Pos } \\
? ?\end{array}$ & No information available & Friedman et $a^{11}$ (pat No 2) \\
\hline 17 & Healthy 50 & $\begin{array}{l}\text { BRCA1 } \\
\text { BRCA2 }\end{array}$ & $\begin{array}{l}\text { 185delAG } \\
\text { 6174delT }\end{array}$ & $\begin{array}{l}\text { Pos } \\
? ?\end{array}$ & No information available & Friedman et $a l^{11}$ (pat No 3) \\
\hline 18 & BC $45(\underline{46})$ & $\begin{array}{l}\text { BRCA1 } \\
\text { BRCA2 }\end{array}$ & $\begin{array}{l}\text { 5382insC } \\
\text { 6174delT }\end{array}$ & $\begin{array}{l}\text { Pos } \\
? ?\end{array}$ & 5382ins $C$ assumed to be maternal & Friedman et $a l^{11}$ (pat No 4) \\
\hline 19 & BC 35 & $\begin{array}{l}\text { BRCA1 } \\
\text { BRCA2 }\end{array}$ & $\begin{array}{l}2508 \mathrm{G} \rightarrow \mathrm{T} \\
3295 \mathrm{ins} \mathrm{A}\end{array}$ & $\begin{array}{l}\text { Pos } \\
\text { Pos }\end{array}$ & $\begin{array}{l}\text { Mother neither mutation, no other family } \\
\text { members available }\end{array}$ & Liede et al ${ }^{12}$ \\
\hline 20 & BC 30 and $O C 41$ & $\begin{array}{l}\text { BRCA1 } \\
\text { BRCA2 }\end{array}$ & $\begin{array}{l}\text { 3888delGA } \\
\text { 6174delT }\end{array}$ & $\begin{array}{l}\text { Pos } \\
\text { Neg. }\end{array}$ & $\begin{array}{l}\text { Mother and sister 6174delT; father } \\
\text { 3888delGA }\end{array}$ & Randall et $\mathrm{al}^{7}$ \\
\hline 21 & $\mathrm{BC}<40$ & $\begin{array}{l}\text { BRCA1 } \\
\text { BRCA2 }\end{array}$ & $\begin{array}{l}\text { 3888delGA } \\
\text { 6174delT }\end{array}$ & $\begin{array}{l}? ? \\
? ?\end{array}$ & $\begin{array}{l}\text { Father 6174delT; neither parent 3888delGA; } \\
\text { 3888delGA assumed paternal de novo }\end{array}$ & Tesoriero ef $a l^{13}$ \\
\hline $\begin{array}{l}22 \\
23\end{array}$ & $\begin{array}{l}\text { Index healthy } 36 \\
\text { Mother OC } 36 \dagger\end{array}$ & $\begin{array}{l}\text { BRCA1 } \\
\text { BRCA2 }\end{array}$ & $\begin{array}{l}\text { 185delAG } \\
\text { 6174delT }\end{array}$ & $\begin{array}{l}\text { Pos } \\
\text { Pos }\end{array}$ & $\begin{array}{l}\text { Brother and father neither mutation; sister } \\
\text { only } 185 \text { delAG; mother assumed carrier } \\
\text { of both mutations }\end{array}$ & Moslehi et al ${ }^{14}$ \\
\hline 24 & BC 33 and 44 and 47 & $\begin{array}{l}\text { BRCA1 } \\
\text { BRCA2 }\end{array}$ & $\begin{array}{l}\text { 5382insC } \\
\text { 6174delT }\end{array}$ & $\begin{array}{l}\text { Neg } \\
\text { Pos }\end{array}$ & No information available & Bell et al ${ }^{15}$ \\
\hline $\begin{array}{l}25 \\
26 \\
27 \\
28 \\
29 \\
30 \\
31\end{array}$ & $\begin{array}{l}\text { Index BC } 28 \\
\text { Mother healthy } 70 \\
\text { Sister healthy } 40 \\
\text { Cousin healthy } 47 \\
\text { Cousin healthy } 41 \\
\text { Aunt BC } 70 \\
\text { Aunt BC } 66\end{array}$ & $\begin{array}{l}\text { BRCA1 } \\
\text { BRCA2 }\end{array}$ & $\begin{array}{l}5242 \mathrm{C} \rightarrow \mathrm{T} \\
6503 \mathrm{delTT}\end{array}$ & $\begin{array}{l}\text { Pos } \\
\text { ?? }\end{array}$ & Mother both mutations & Caldes et al ${ }^{16}$ \\
\hline
\end{tabular}


Table 1 Continued

\begin{tabular}{|c|c|c|c|c|c|c|}
\hline No & DH (index) cases* & Mutatior & & $\begin{array}{l}\text { FH: } \\
\text { maternal/ } \\
\text { paternal§ }\end{array}$ & Inheritance confirmed? & Reference \\
\hline $\begin{array}{l}32 \\
33\end{array}$ & $\begin{array}{l}\text { Index BC } 33 \\
\text { Mother stomach cancer } 62\end{array}$ & $\begin{array}{l}\text { BRCA1 } \\
\text { BRCA2 }\end{array}$ & $\begin{array}{l}\text { E1661X } \\
6174 \text { del4 }\end{array}$ & $\begin{array}{l}\text { Neg } \\
\text { Neg }\end{array}$ & Mother both mutations & Choi et al ${ }^{20}$ (pat 60071) \\
\hline 34 & Index BC 26 & $\begin{array}{l}\text { BRCA1 } \\
B R C A 2\end{array}$ & $\begin{array}{l}\text { 1635del5 } \\
\text { 3026delCA }\end{array}$ & $\begin{array}{l}\text { Neg } \\
\text { Neg }\end{array}$ & No information available & Choi et al ${ }^{20}$ (pat 60351) \\
\hline
\end{tabular}

*Diagnosis, age at diagnosis (years); ( _ ), age at last follow up. †Assumed to have both mutations.

†Documented founder mutations in bold type; 185 delAG and 187delAG are identical, 5382ins $\mathrm{C}$ and $5385 \mathrm{ins}$ are identical. §Family history of breast and/or ovarian cancer.

AZG, Groningen University Hospital; BC, breast cancer; Bilat, bilateral; DH, double heterozygosity; FH, family history; Neg, negative; OC, ovarian cancer; Pos, positive; UMCN, University Medical Centre Nijmegen; ??, no information available.

Satagopan et al,,$^{30}$ Warner et al, ${ }^{31}$ and Robson et al, ${ }^{32}$ there was mention of double heterozygotes, but they were not included because of lack of clinical information. We are aware of three males with DH: one man described by Caldes et $a l^{16}$ who had prostate cancer at age 66; one healthy man of over 50 in the series of Frank et $a l^{23}$; and one brother of case 1 , who is healthy at age 63. These were also not included in the analysis.

\section{RESULTS}

The data on all 34 informative women are given in table 1. The women originated from 25 families, and most cases of DH were the only ones known in the family, the clearest exception being the large family from Spain. ${ }^{16}$ Excluding the two Korean families for which no population data were available, ${ }^{20}$ we found that in all but two families (index 19 and index 25) at least one of the detected mutations was a known founder in the population. In several families Ashkenazi Jewish descent was known before testing, and DNA analysis was often restricted to founder mutations. In 17 of 25 families (19 women) two Ashkenazi founder mutations were detected, whereas in two families (two women) such a founder mutation was detected only in BRCA2 (6174delT). In many of the 25 families, the information on family history of cancer was inadequate, most often on the paternal side; this is likely to reflect the method of ascertainment. From 18 informative families, the maternal

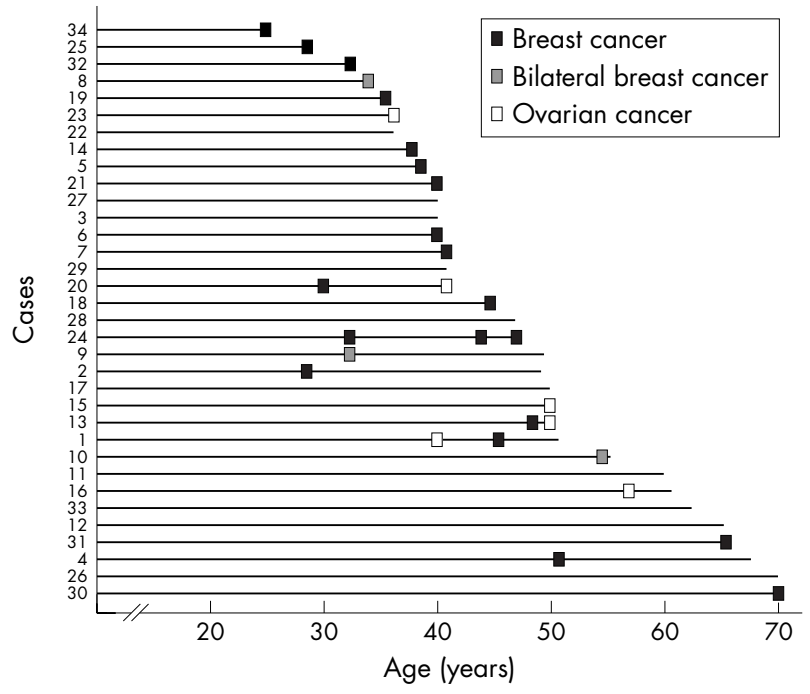

Figure 2 Age related penetrance in 34 cases with double heterozygosity. (family) history was positive in 13 cases, the paternal family history was positive in only one case, and there was a history of breast/ovarian cancer on both sides of the family in four.

Of the 34 women with $\mathrm{DH}, 10$ were without breast/ovarian cancer (mean age at last follow up 51.3 years (range 36 to $70)$ ) and $24(71 \%)$ had developed breast or ovarian cancer or both. Fourteen women had one primary breast cancer (mean age at diagnosis 41.3 years (range 26 to 70 )), three had bilateral breast cancer (mean age at diagnosis 40.7 years (range 33 to 55)), and one had three primary breast cancers (at age 33,44, and 47). Three women were diagnosed with both breast and ovarian cancer (mean age at first cancer 39.3 years (range 30 to 48 ); mean age for breast cancer 41.0 years (range 30 to 48 ); mean age for ovarian cancer 43.7 years (range 40 to 50$)$ ). Three women had ovarian cancer only (mean age 47.7 years (range 36 to 57)). In 13 of 24 women (54\%) the first cancer was diagnosed before the age of 40 ,

\begin{tabular}{|l|r|r|r|r|r|r|}
\hline & $0-20$ & $21-30$ & $31-40$ & $41-50$ & $51-60$ & $61-70$ \\
\hline Entering & 34 & 34 & 30 & 16 & 9 & 6 \\
\hline Events & 0 & 4 & 11 & 4 & 3 & 2 \\
\hline Censored & 0 & 0 & 3 & 3 & 0 & 4 \\
\hline Person years & 680 & 332 & 253 & 132 & 73 & 35 \\
\hline
\end{tabular}

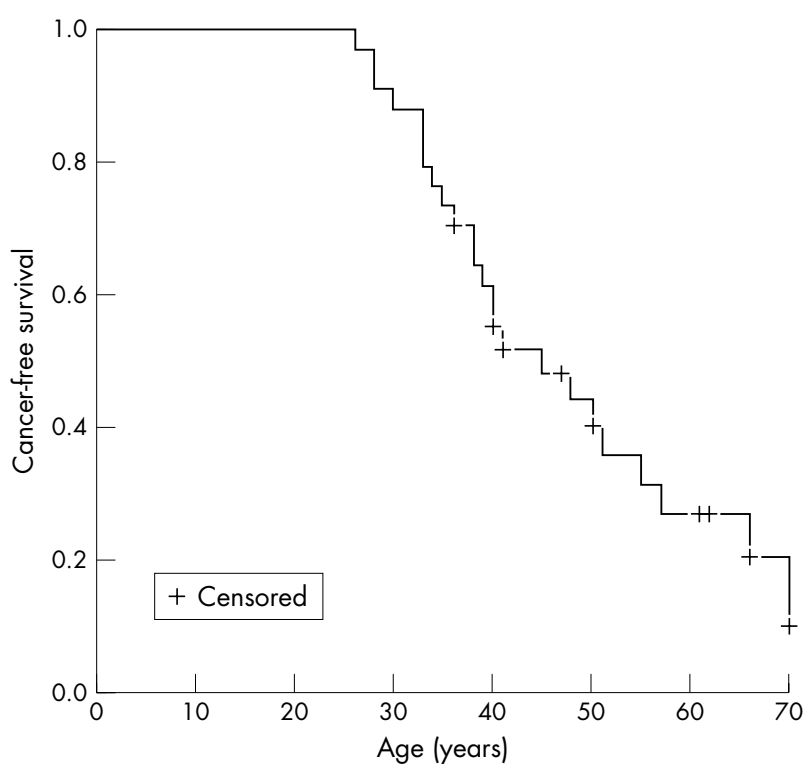

Figure 3 Kaplan-Meier curve for tumour-free survival in cases with double heterozygosity. Cases are left censored at age of first cancer or at age at last follow up. 


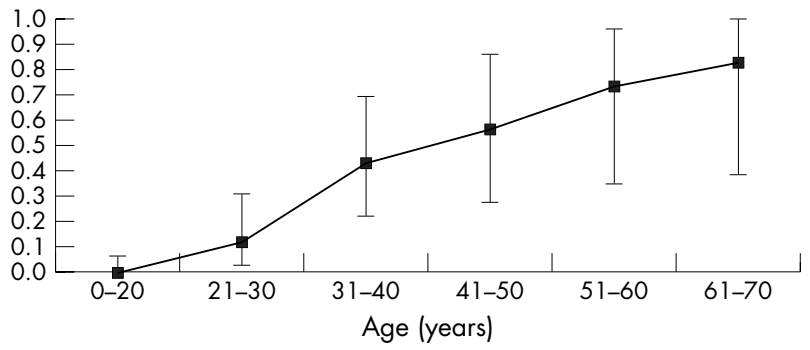

Figure 4 Cumulative incidence rate of breast/ovarian cancer in cases with double heterozygosity (risk and 95\% confidence interval).

which is $38 \%$ of the total group (13/34). These figures are likely to be skewed owing to differences in follow up time.

The total number of primary cancers in 24 affected women was 32 (26 breast, six ovarian) at a mean onset age of 42.3 years (range 26 to 70 ). The mean age at diagnosis for all breast cancers was 41.1 years (range 26 to 70 ), and for all ovarian cancers, 45.7 years (range 36 to 57). Cancer events in all 34 women with $\mathrm{DH}$ are depicted longitudinally in fig 2 . Follow up data on reported cases often stopped at the age of cancer diagnosis or at the age of DNA testing. Only in four cases with DH was detailed information available on prophylactic surgery: case 1, unilateral mastectomy at age 50; case 2, bilateral salpingo-oophorectomy at age 49; case 3, bilateral mastectomy at age 35 and salpingo-oophorectomy at age 36; and case 4, no prophylactic surgery. These data influence their residual risk of developing cancer in the following years, and for this reason they were censored in the Kaplan-Meier analysis. Information on the extent of breast cancer treatment (that is, mastectomy or breast conserving therapy, radiotherapy, chemotherapy, or hormonal therapy), which may also affect the risk of subsequent cancers, was also unavailable on most cases, so this could not be taken into account. Of the 32 cancers that developed in 24 women with $\mathrm{DH}, 15(47 \%)$ were diagnosed before the age of 40 . Because the follow up time varied among the cases, the cancer-free survival curve (which only takes first cancers into account) was censored for missing follow up years (fig 3); it shows a median cancer-free survival of 45 years (95\% confidence interval, 33 to 57). Figure 4 gives the cumulative incidence proportion of cancer in $\mathrm{DH}$; by 70 years of age this was $84 \%$ (38\% to $99 \%)$ for breast and ovarian cancer combined.

In our series there were three recurrent genotypic combinations of $\mathrm{DH}$. The phenotypic expression is summarised in table 2. Thirteen women had 185delAG/6174delT, of whom four were healthy (mean age 48 years (range 36 to $66)$ ) and nine (69\%) had a total of 12 cancers (four ovarian, eight breast). Three women had multiple cancers. Six cases had 5382insC/6174delT, of whom one was without cancer at 61 years, and five $(83 \%)$ had a total of eight cancers (eight breast cancers, no ovarian). Two women had multiple cancers. Seven cases had the 5242C $\rightarrow$ T/6503delTT genotype involving a missense mutation in BRCAl, of whom four were healthy (mean age 50 years (range 41 to 70 )) and three (43\%) had a total of three cancers (all breast).

To assess the contribution of both mutations in tumour development in case 1, loss of heterozygosity ( $\mathrm{LOH}$ ) analysis was carried out on DNA isolated from paraffin embedded breast and ovarian tumour tissue. DNA from peripheral blood and from paraffin embedded normal tissue from the proband was used as control. Sequence analysis around the mutation sites revealed loss of the wild type allele at the BRCAl locus in the breast tumour tissue as well as in the ovarian tumour specimen. LOH data for the BRCA2 gene showed predominant loss of the wild type allele in breast cancer tissue. However, in ovarian cancer tissue predominant loss of the mutant allele was detected.

The data above were added to the $\mathrm{LOH}$ analyses that have been reported previously in seven breast cancer and two ovarian cancer specimens (table 3 ). In three of eight breast cancers, $\mathrm{LOH}$ for BRCAl was detected, and in four (although incomplete in case 1) of eight for BRCA2. Two breast cancers did not show LOH for either gene. The data on ovarian tissue are very inconclusive: one tumour had $\mathrm{LOH}$ for both genes, one had no LOH for either gene, and one tumour (case 1) had loss of the wild type allele for BRCAI but predominant loss of the mutant allele for BRCA2.

\section{DISCUSSION}

Serendipitous detection of $\mathrm{DH}$ for $B R C A 1$ and $B R C A 2$ prompted us to collect and review all available cases with DH. Thirty cases have been described since 1997, from different countries with highly variable ways of ascertainment ranging from research programmes targeted at Ashkenazi populations to case referral to clinical genetics

Table 2 Phenotype-genotype correlation in recurrent mutation combinations

\begin{tabular}{|c|c|c|c|c|c|c|c|c|}
\hline Genotype & $\mathbf{n}$ & $\mathrm{Age}^{*}$ & $\begin{array}{l}\text { FU years ( } 25 \\
\text { and older) }\end{array}$ & $\begin{array}{l}\text { Affected/ } \\
\text { non-affected }\end{array}$ & $\mathrm{BC} \dagger$ & $\mathrm{OC} \dagger$ & $\begin{array}{l}\text { Cancers } \\
\text { per carrier }\end{array}$ & $\begin{array}{l}\text { Cancers per } \\
\text { FU-year } \\
>25\end{array}$ \\
\hline 5382insC/6174delT & 6 & $52(40$ to 61$)$ & 151 & $5 / 1$ & $8(40 ; 33$ to 51$)$ & 0 & 1.33 & 0.053 \\
\hline 185delAG/6174delT & 13 & 48 (36 to 66$)$ & 253 & $9 / 4$ & $8(43 ; 34$ to 55$)$ & $4(48 ; 36$ to 57$)$ & 0.92 & 0.047 \\
\hline $5242 \mathrm{C} \rightarrow \mathrm{T} / 6503$ delTT & 7 & $52(28$ to 70$)$ & 177 & $3 / 4$ & $3(55 ; 28$ to 70$)$ & 0 & 0.43 & 0.017 \\
\hline
\end{tabular}

${ }^{*}$ Mean (range).

$\mathrm{tn}$ (mean age at diagnosis; range).

BC, breast cancer; FU, follow up; OC, ovarian cancer

Table $3 \mathrm{LOH}$ data in reported cases of $B R C A 1 / B R C A 2$ double heterozygosity

\begin{tabular}{|c|c|c|c|c|c|c|c|c|c|c|c|c|c|}
\hline & \multicolumn{9}{|c|}{ Breast cancer tissue (case No) } & \multicolumn{4}{|c|}{ Ovarian cancer tissue (case No) } \\
\hline & 13 & 20 & 21 & $24 a$ & $24 b$ & $24 c$ & 25 & 1 & Total & 13 & 20 & 1 & Total \\
\hline LOH BRCAI & - & + & - & - & - & + & - & + & $3 / 8$ & - & + & + & $1 / 3$ \\
\hline LOH BRCA2 & - & - & + & + & + & - & - & $+1-$ & $3 / 7$ & - & + & $-{ }^{*}$ & $1 / 2$ \\
\hline
\end{tabular}


services. This has most probably led to a publication bias: some cases may be unreported, and an overrepresentation of Ashkenazi Jewish cases with founder mutations is likely.

\section{Prevalence}

The chance of detecting DH depends largely on the frequency of mutation carriers in the reference population, but also on the availability of clinical genetic knowledge and services, the extensiveness of family history taking, the inclusion criteria used for DNA testing, and the extent and procedures of molecular analysis. These are all very heterogeneous-for example, genetic testing may vary from only an analysis of the three well known Jewish founder mutations to comprehensive mutation analysis of the whole coding regions. The population carrier frequency of 185delAG, 5382insC (BRCAI), and 6174delT (BRCA2) is estimated to be $0.92,0.26$, and 1.20 , respectively, in the Ashkenazi population, ${ }^{40}$ adding up to approximately $2.4 \%$. Peto et al estimated the prevalence of BRCA1 and BRCA2 mutation carriers to be $0.11 \%$ and $0.12 \%$, respectively, in the non-Ashkenazi (UK) population, which adds up to $0.23 \% .^{33}$ This indicates that the chance occurrence of double heterozygosity in these populations is around 1 in 1800 and 1 in 190000 , respectively. However, as DNA analysis in the diagnostic setting is usually done on the basis of medical history, family history, and ethnicity, the chance of finding $\mathrm{DH}$ among these selected cases must be substantially higher regardless of whether the phenotype is more severe in DH. The data of Frank et al ${ }^{23}$ allow an estimation of the incidence of DH in a DNA diagnostic setting: 11 cases of DH were identified among 1720 patients with a positive test result $(0.64 \%)$ - that is, 11 of 10000 cases tested $(0.1 \%)$. All cases of DH were of Ashkenazi descent ( 11 of 617 positive cases $(1.8 \%) ; 11$ of 3022 tested $(0.36 \%))$. No cases of DH were detected among at least 6724 non-Ashkenazi individuals in whom full sequencing of BRCAI and BRCA2 revealed 1054 mutations. Case 1 is the only one detected in 115 mutation positive index cases tested in Groningen $(0.87 \%)$, which amounts to $0.14 \%(1 / 739)$ of all index cases tested to date. Case 2 is the only one of 187 positive index cases in Nijmegen $(0.53 \%)$, which amounts to $0.09 \%(1 / 1115)$ of all index cases tested. Data from the Dutch-Belgian working group on BRCA mutation screening suggest a lower incidence $(0.22 \%)$, as only three cases of $\mathrm{DH}$ are known in 1390 mutation positive families (Hogervorst F, personal communication). Though based on different laboratory methods, populations, and ascertainment criteria (the percentage of index cases with cancer is most probably greater in the Dutch data than in the data of Frank et al), the overall incidences from Groningen, Nijmegen, and Frank et al are similar. The latter data, however, clearly show that Ashkenazi Jewish descent is the single most important predictor of $\mathrm{DH}$. Moreover table $\mathrm{l}$ shows that the presence of any founder mutation (also nonAshkenazi) is very common in DH.

As is illustrated in the family of case 1 and in several reported cases, finding two mutations has immense consequences for genetic counselling of relatives at risk. First, for first degree relatives, the chance of inheriting one or two mutations is $50 \%$ and $25 \%$, respectively, amounting to a $75 \%$ chance of having a very high risk of breast and ovarian cancer. Second, if presymptomatic testing is carried out in a family where only one mutation is uncovered, this could lead to a false reassurance of tested relatives. In only four of 18 informative families reported here $(22 \%)$ could the possibility of $\mathrm{DH}$ be suspected before testing, because family history was positive for breast or ovarian cancer on both the maternal and the paternal sides. Some years ago, Gershoni-Baruch et al recommended that one should always test for all three founder mutations in individuals with Jewish ancestry. ${ }^{19}$ We suggest that in index cases that meet the criteria for molecular testing and have breast or ovarian cancer on both the maternal and the paternal sides of the family, mutation screening of the whole BRCAI and BRCA2 gene should be completed, ${ }^{34}$ especially when the (first) mutation detected is a known founder in the population. If a mutation is detected in a family, it is important to try to confirm co-segregation in all affected family members. Moreover, if a known mutation (previously detected in the family) is not found in a relative with breast or ovarian cancer, one could consider screening for other (founder) mutations before concluding that the index case is a phenocopy. However, genes other than BRCAI and $B R C A 2$ could also be involved. The likelihood that a (nonAskenazi) index case with a non-founding BRCA mutation has inherited a second mutation from the unaffected side is much less than $1 \%$. It is probably a more logical use of resources to extend the availability of BRCA testing to moderate risk groups than to put more effort into full sequencing of BRCA1 and BRCA2 in these BRCA mutation carriers.

\section{LOH analysis}

$B R C A 1$ and BRCA2 both act as tumour suppressor genes, and their gene products play a role in different parts of the complex process of DNA repair. We tried to assess which mutation was the predominant one in oncogenesis in $\mathrm{DH}$ in the two different tumour tissues in case 1. Analysis of LOH revealed that the mutation in BRCAl is most probably the causative mutation in both the breast tumour and the ovarian tumour. The role of the BRCA2 mutation, however, is less clear. In the breast tumour there is loss of the wild type allele only in part of the cells. This is not a result of admixture with normal cells, because in the same DNA sample LOH is complete at the BRCAl locus. Perhaps loss of the second $B R C A 2$ allele plays a greater role in tumour progression than in the origin of this breast cancer. In the ovarian tumour there is loss of the mutant BRCA2 allele. Some loss of alleles can be random owing to the known chromosomal instability that occurs with mutations in the BRCA genes. From table 3 one cannot deduce whether there is a preference for $B R C A I$ or $B R C A 2$ to be the first gene to lose its function completely. This is especially clear from the data of Bell et al, who studied three breast tumours from one patient. In two of these they found $\mathrm{LOH}$ for $B R C A 2$ and in the third tumour $\mathrm{LOH}$ for $B R C A 1 .{ }^{15}$ In the cases where no $\mathrm{LOH}$ for either gene was found, this may reflect admixture of normal tissue in the tumour preparation, as was suggested by Ramus et al. ${ }^{10}$ Only three ovarian tumours were evaluated for $\mathrm{LOH}$ and there was no preference for loss of BRCA1 or BRCA2. In cases where no $\mathrm{LOH}$ for either gene is found, contamination with normal tissue might again have played a role. Randall et al described LOH for both genes. ${ }^{7}$ However, with the technique they used (analyses of CA repeats in blood and tumour of the patients, but not in the parents) it is not possible to distinguish between loss of the wild type allele and loss of the mutant allele, as was found in the ovarian tumour from our patient. Overall, we have no indication yet that either the BRCAl or $B R C A 2$ mutation plays a predominant role in oncogenesis in $\mathrm{DH}$.

\section{Phenotypic expression of DH}

Assessment of the age related cancer incidence in $\mathrm{DH}$ is difficult for several reasons. First, it is a small and heterogeneous group from different populations and ascertained in different ways. Second, in most cases data on risk modifying factors (for example, the number of pregnancies, prophylactic surgery, oral contraceptives, hormone replacement therapy, and so on) are lacking. Third, in affected cases details of the mode of detection (screening or interval), multifocality, and treatment methods (mastectomy, breast 
conserving treatment, radiotherapy, chemotherapy, or adjuvant treatment) are missing.

The age related phenotypic expression in this small series of 34 female cases of $\mathrm{DH}$ appeared to be highly variable (fig 3). Ten women of the 34, with a mean age of 51.3 years (range 36 to 70), were without cancer. For most of these there were no data on risk modifying factors, so this group is not only very small but probably also heterogeneous. KaplanMeier analysis shows a median cancer-free survival of 45 years (95\% confidence interval, 33 to 57), which is comparable with the average age for breast cancer diagnosis in BRCA1 and BRCA2 mutation carriers. The cumulative incidence proportion of cancer in DH at age 70 is $80 \%$ for breast cancer only and $84 \%$ for breast and ovarian cancer. This is comparable with the age related expression of breast cancer in large family based series of BRCA mutation carriers $(85 \%$ and $84 \%$ risk of breast cancer at age 70 for BRCA1 and BRCA2, respectively)..$^{35}$ However, comparison with data from Ashkenazi populations may be more appropriate given the large number of Ashkenazi founder mutations in our series. The risks we found here in DH were higher than reported in population based data by Struewing et al $(40-73 \%$ at age 70 for $B R C A l),{ }^{37}$ by Warner et al $\left(60 \%\right.$ at age 70 for BRCAl), ${ }^{31}$ or by Satagopan et al (31-80\% at age 70 for BRCAl and $14-50 \%$ for $B R C A 2),{ }^{30}$ but comparable to the family based data of Brose et al, with $37 \%$ Ashkenazi cases $(74-82 \%$ by age 70 for $B R C A 1),{ }^{38}$ and the population based data of King et al (69\% for BRCA1 and $74 \%$ for BRCA2 at age 70). ${ }^{39}$

Brose et al, who had 37\% Ashkenazi founder mutations in their study of 483 BRCAl mutation carriers, estimated the risk of a second cancer in their population: $22 \%$ of women had a second breast cancer (age adjusted lifetime risk 34-47\%), and $15 \%$ had ovarian cancer after a previous breast cancer (age adjusted lifetime risk $14-24 \%){ }^{38}$ In our series four breast cancer patients had a second breast cancer $(21 \%)$ and two breast cancer patients subsequently had ovarian cancer ( $11 \%)$. If we include case 1 , who had ovarian cancer before breast cancer, the percentage is $16 \%(3 / 19)$, and these percentages are remarkably similar to those of Brose et al. This means that on the basis of this small series there is no indication that double primary tumours occur more often in women with DH.

\section{Genotype-phenotype correlation}

Though the data on the three recurrent phenotypes are insufficient for statistical analysis, they indicate that 5382insC/6174delT gives the highest cancer risk-that is, the highest ratio of affected $\mathrm{DH}$ cases (5/6), the highest number of cancers per carrier (1.33) and per affected case (1.6), the highest ratio of multiple cancers, and the lowest mean age at diagnosis (40 years) (table 2). The 185delAG/ 6174delT is the only recurrent DH that caused ovarian cancer, leading to cancer in $69 \%$ of DH cases, with 0.92 cancers per carrier and 1.3 cancers per affected case. However, when the cancer incidence is correlated with the number of follow up years above the age of 25 ( 0.053 and 0.047 , respectively), the difference becomes negligible. The $5242 \mathrm{C} \rightarrow \mathrm{T} / 6503$ delTT combination gives the lowest risk and the oldest average age of onset, which may be a reflection of the fact that we are dealing with a missense mutation in BRCAl (which makes its pathogenicity less certain) and with members of only one family.

It is difficult to compare these results (that is, 185delAG/ 6174delT and 5382insC/6174delT) with the published data on founder mutation specific penetrance. Struewing et al concluded that the apparent cancer risk was highest for the 5382insC mutation in BRCAl and, surprisingly, that the ovarian cancer risk was highest in 5382insC and lowest in 185delAG. ${ }^{37}$ Brose et al found comparable results, with a lower ovarian cancer risk in 185 delAG carriers. ${ }^{38}$ Others found that the penetrance of 185 delAG and 5382insC was comparable, although the latter mutation was observed much more often than expected, suggesting a higher penetrance. ${ }^{40}$

\section{Conclusions}

Double heterozygosity for BRCA1 and BRCA2 mutations is a rare phenomenon, with an incidence of $0.22-0.87 \%$ among $B R C A$ mutation carriers, though among Ashkenazi Jewish cases the percentage may be as high as $1.8 \%$. Analysis of 34 cases with DH shows that the phenotypic expression is comparable to the severe end of the spectrum of BRCAI mutation carriership. There is no indication of a more severe expression with respect to age of onset, cumulative lifetime risks, and the chance of multiple primary tumours. This implies that the usual cancer risk management and preventive options available to high risk women can be offered to women with DH as well. However, the numbers are small and it is therefore important to monitor the follow up of all women with DH. Data on LOH analysis in both breast and ovarian tumours of women with DH are very limited and do not suggest a predominant contribution of either BRCAI or $B R C A 2$ to oncogenesis in these women.

The main difference in counselling between carriers of a single mutation and people with $\mathrm{DH}$ lies in the risks for first degree relatives and other family members. These are confronted with a risk of carrying a mutation up to $75 \%$, and could be falsely reassured if only one familial mutation is excluded while an unrecognised one could still be present. This underlines the need for thorough family investigation once DH is detected in an index case. Before DNA analysis, the presence of $\mathrm{DH}$ was suspected only in a small minority on the basis of family history. When a BRCAl or BRCA2 mutation is detected in an index case, we suggest that co-segregation of the mutation with the diseases should always be assessed in order confirm that the detected mutation is sufficient to explain the family history. When there is a positive family history on both sides, when the first detected mutation is a founder mutation, or when there is Ashkenazi Jewish descent, further mutation analysis of BRCA1 and BRCA2 should be considered before concluding that an affected relative without the familial mutation is a phenocopy.

\section{ACKNOWLEDGEMENTS}

$\mathrm{RE}$ is funded by The Institute of Cancer Research. JB and EB are funded by Cancer Research UK. AS is funded by the Barclay Foundation. We thank M Schaapveld for methodological discussion and Professor D G Evans for critical comments on the manauscript.

\section{Authors' affiliations}

B Leegte, A H van der Hout, M K Bakker, I M Mulder, A ten Berge, E P Leenders, J C Oosterwijk, Department of Clinical Genetics, Groningen University Medical Centre, Groningen, Netherlands A M Deffenbaugh, Myriad Genetic Laboratories Inc, Salt Lake City, Utah, USA

J Wesseling, Department of Pathology, Groningen University Medical Centre

J de Hullu, Department of Obstetrics and Gynaecology, University Medical Centre St Radboud, Niimegen, Netherlands

N Hoogerbrugge, M J L Ligtenberg, Department of Clinical Genetics, University Medical Centre St Radboud

A Ardern-Jones, E Bancroft, Cancer Genetics Unit, Institute of Cancer Research, Royal Marsden Hospital, Sutton, Surrey, UK

A Salmon, Haddassah Oncology Centre, Hadassah, Jerusalem, Israel J Barwell, Clinical Genetics Department, St George's NHS Trust, London SW17, UK

R Eeles, Translational Cancer Genetics Team, Institute of Cancer Research, Sutton, Surrey, UK

Competing interests: none declared 
Correspondence to: Dr Jan C Oosterwijk, Department of Clinical Genetics, Groningen University Medical Centre, PO Box 30.001, NL9700 RB Groningen, The Netherlands; j.c.oosterwijk@medgen.azg.nl

\section{REFERENCES}

1 Oosterwijk JC, Kliin JG. Present guidelines for referral and management when familial/hereditary breast (-ovarian) cancer is suspected. South West Cancer News 1995; 1:10-12.

2 Eccles DM, Evans DG, Mackay J. Guidelines for a genetic risk based approach to advising women with a family history of breast cancer. UK Cancer Family Study Group (UKCFSG). J Med Genet 2000;37:203-9.

3 Hampel H, Sweet K, Westman JA, Offit K, Eng C. Referral for cancer genetics consultation: a review and compilation of risk assessment criteria. J Med Genet 2004;41:81-91.

4 Fodor FH, Weston A, Bleiweiss IJ, McCurdy LD, Walsh MM, Tartter PI, Brower ST, Eng CM. Frequency and carrier risk associated with common BRCA1 and BRCA2 mutations in Ashkenazi Jewish breast cancer patients. Am J Hum Genet 1998;63:45-51.

5 Stoppa-Lyonnet D, Fricker JP, Essioux L, Pages S, Limacher JM, Sobol H, Laurent-Puig $P$, Thomas $G$. Segregation of two BRCA1 mutations in a single family. Am J Hum Genet 1996;59:479-81.

6 Loader S, Rowley PT. Deleterious mutations of both BRCA1 and BRCA2 in three siblings. Genet Test 1998;2:75-7.

7 Randall TC, Bell KA, Rebane BA, Rubin SC, Boyd J. Germline mutations of the BRCA1 and BRCA2 genes in a breast and ovarian cancer patient. Gynecol Oncol 1998;70:432-4.

8 Gershoni-Baruch R, Dagan E, Kepten I, Fried G. Co-segregation of BRCAI 185delAG mutation and BRCA2 6174delT in one single family. Eur J Cancer 1997;33:2283-4.

9 Ganguly A, Citron M, Godmilow L, Ahrens M, Ganguly T. Caucasian family with two independent mutations: 2594delC in BRCA1 and 5392delAG in BRCA2 gene. Am J Med Genet 2001; 101:146-52.

10 Ramus SJ, Friedman LS, Gayther SA, Ponder BA, Bobrow L, van der LM, Papp J, Olah E. A breast/ovarian cancer patient with germline mutations in both BRCA1 and BRCA2. Nat Genet 1997;15:14-15.

11 Friedman E, Bar-Sade Bruchim R, Kruglikova A, Risel S, Levy-Lahad E, Halle D, Bar-On E, Gershoni-Baruch R, Dagan E, Kepten I, Peretz T, Lerer I, Wienberg N, Shushan A, Abeliovich AD. Double heterozygotes for the Ashkenazi founder mutations in BRCA1 and BRCA2 genes. Am J Hum Genet 1998:63:1224-7.

12 Liede A, Rehal P, Vesprini D, Jack E, Abrahamson J, Narod S. A breast cancer patient of Scottish descent with germ-like mutations in BRCA1 and BRCA2. Am J Hum Genet 1998;62:1543-4.

13 Tesoriero A, Andersen C, Southey M, Somers G, McKay M, Armes J, McCredie M, Giles G, Hopper JL, Venter D. De novo BRCA1 mutation in a patient with breast cancer and an inherited BRCA2 mutation. Am J Hum Genet 1999;65:567-9.

14 Moslehi R, Russo D, Phelan C, Jack E, Antman K, Narod S. An unaffected individual from a breast/ovarian cancer family with germline mutations in both BRCA1 and BRCA2. Clin Genet 2000;57:70-3

15 Bell DW, Erban J, Sgroi DC, Haber DA. Selective loss of heterozygosity in multiple breast cancers from a carrier of mutations in both BRCA1 and BRCA2. Cancer Res 2002;62:2741-3.

16 Caldes T, de la HM, Tosar A, Sulleiro S, Godino J, Ibanez D, Martin M, Perez Segura P, Diaz-Rubio E. A breast cancer family from Spain with germline mutations in both the BRCA1 and BRCA2 genes. J Med Genet 2002;39:e44

17 Cortesi L, Turchetti D, Bertoni C, Zanocco-Marani T, Vinceti M, Silvestri C, Federico $M$, Silingardi $V$, Ferrari S. Italian family with two independent mutations: 3358T/A in BRCA1 and 8756delA in BRCA2 genes. Eur J Hum Genet 2003;11:210-14.

18 Liede A, Metcalfe K, Offit K, Brown K, Miller S, Narod SA, Moslehi R. A family with three germline mutations in BRCA1 and BRCA2. Clin Genet 1998;54:215-18.

19 Gershoni-Baruch R, Dagan E, Kepten I, Fried G. Co-segregation of BRCA1 185delAG mutation and BRCA2 6174delT in one single family. Eur J Cancer 1997;33:2283-4.

20 Choi DH, Lee MH, Bale AE, Carter D, Haffty BG. Incidence of BRCA1 and BRCA2 mutations in young Korean breast cancer patients. J Clin Oncol 2004;22:1638-45.

21 Peelen T, van Vliet $M$, Petrij-Bosch A, Mieremet R, Szabo C, van den Ouweland $A M$, Hogervorst $F$, Brohet $R$, Ligtenberg $M J$, Teugels $E$, van der $L R$, van der Hout AH, Gille JJ, Pals G, Jedema I, Olmer R, van L, I, Newman B, Plandsoen $M$, van der EM, Brink G, Hageman S, Arts PJ, Bakker MM, Devilee $P$. A high proportion of novel mutations in BRCA1 with strong founder effects among Dutch and Belgian hereditary breast and ovarian cancer families. Am J Hum Genet 1997;60:1041-9.

22 van der Hout $A H$, Mulder IM, Wu Y, van der Vlies $P$, Huisman $M$ Oosterwijk JC, Buys CHCM, Hofstra RM. A DGGE system for comprehensive mutation screening of the complete coding regions of $B R C A 1$ and $B R C A 2$ outside exons 11 [abstract]. Am J Hum Genet 1999;65:A410.

23 Frank TS, Deffenbaugh AM, Reid JE, Hulick M, Ward BE, Lingenfelter B, Gumpper KL, Scholl T, Tavtigian SV, Pruss DR, Critchfield GC. Clinical characteristics of individuals with germline mutations in BRCA1 and BRCA2: analysis of 10,000 individuals. J Clin Oncol 2002;20:1480-90.

24 Moslehi R, Chu W, Karlan B, Fishman D, Risch H, Fields A, Smotkin D, Ben David Y, Rosenblatt J, Russo D, Schwartz P, Tung N, Warner E, Rosen B, Friedman J, Brunet JS, Narod SA. BRCA1 and BRCA2 mutation analysis of 208 Ashkenazi Jewish women with ovarian cancer. Am J Hum Genet 2000;66:1259-72.

25 Futreal PA, Liu Q, Shattuck-Eidens D, Cochran C, Harshman K, Tavtigian S, Bennett LM, Haugen-Strano A, Swensen J, Miki Y, et al. BRCA1 mutations in primary breast and ovarian carcinomas. Science 1994 Oct 7i 266(5182): 120-2.

26 Koonin EV, Altschul SF, Bork P. BRCA1 protein products, functional motifs. Nat Genet 1996;13:266-8.

27 Abkevich V, Zharkikh A, Deffenbaugh AM, Frank D, Chen Y, Shattuck D, Skolnick MH, Gutin A, Tavtigian SV. Analysis of missense variation in human BRCA1 in the context of interspecific sequence variation, J Med Genet 2004;41:492-507.

28 Osorio A, De La Hoya M, Rodriguez-Lopez R, Martinez-Ramirez A, Cazorla A, Granizo JJ, Esteller M, Rivas C, Caldes T, Benitez J. Loss of heterozygosity analysis at the BRCA loci in fumor samples from patients with familial breast cancer. Int J Cancer 2002;99:305-9.

29 Tsongalis GJ, Linfert DR, Johnson RC, Ackroyd R, Berman MM, Ricci A Jr. Double heterozygosity for mutations in the BRCA1 and BRCA2 genes in a breast cancer patient. Arch Pathol Lab Med 1998;122:548-50.

30 Satagopan JM, Offit K, Foulkes W, Robson ME, Wacholder S, Eng CM, Karp SE, Begg CB. The lifetime risks of breast cancer in Ashkenazi Jewish carriers of BRCA1 and BRCA2 mutations. Cancer Epidemiol Biomarkers Prev $2001 ; 10: 467-73$

31 Warner E, Foulkes W, Goodwin P, Meschino W, Blondal J, Paterson C, Ozcelik H, Goss P, Allingham-Hawkins D, Hamel N, Di Prospero L, Contiga V, Serruya C, Klein M, Moslehi R, Honeyford J, Liede A, Glendon C, Brunet JS, Narod S. Prevalence and penetrance of BRCA1 and BRCA2 gene mutations in unselected Ashkenazi Jewish women with breast cancer. J Natl Cancer Inst 1999;91:1241-7

32 Robson $M$, Levin D, Federici $M$, Satagopan J, Bogolminy F, Heerdt A Borgen P, McCormick B, Hudis C, Norton L, Boyd J, Offit K. Breast conservation therapy for invasive breast cancer in Ashkenazi women with BRCA gene founder mutations. J Natl Cancer Inst 1999;91:2112-17.

33 Peto J, Collins N, Barfoot R, Seal S, Warren W, Rahman N, Easton DF, Evans C, Deacon J, Stratton MR. Prevalence of BRCA1 and BRCA2 gene mutations in patients with early-onset breast cancer. J Natl Cancer Inst 1999;91:943-9.

34 Mueller C, Haworth A. Draft best practice guidelines for molecular analysis of hereditary breast and ovarian cancer. European Molecular Genetic Quality Network, 2001, www.emqn.org/bpguidelines.

35 Easton DF, Ford D, Bishop DT. Breast and ovarian cancer incidence in BRCA1mutation carriers. Am J Hum Genet 1995:56:265-71.

36 Ford D, Easton DF, Stratton M, Narod S, Goldgar D, Devilee P, Bishop DT, Weber B, Lenoir G, Chang-Claude J, Sobol H, Teare MD, Struewing J, Arason A, Scherneck S, Peto J, Rebbeck TR, Tonin P, Neuhausen S, Barkardottir R, Eyfjord J, Lynch H, Ponder BA, Gayther SA, ZeladaHedman M. Genetic heterogeneity and penetrance analysis of the BRCA1 and BRCA2 genes in breast cancer families. Am J Hum Genet 1998;62:676-89.

37 Struewing JP, Hartge P, Wacholder S, Baker SM, Berlin M, McAdams M, Timmerman MM, Brody LC, Tucker MA. The risk of cancer associated with specific mutations of BRCA1 and BRCA2 among Ashkenazi Jews. NEngl J Med 1997;336:1401-8.

38 Brose MS, Rebbeck TR, Calzone KA, Stopfer JE, Nathanson KL, Weber BL. Cancer risk estimates for BRCA1 mutation carriers identified in a risk evaluation program. J Natl Cancer Inst 2002;94:1365-72.

39 King MC, Marks JH, Mandell JB. Breast and ovarian cancer risks due to inherited mutations in BRCA1 and BRCA2. Science 2003;302:643-6.

40 Levy-Lahad E, Catane R, Eisenberg S, Kaufman B, Hornreich G, Lishinsky E, Shohat M, Weber BL, Beller U, Lahad A, Halle D. Founder BRCA1 and BRCA2 mutations in Ashkenazi Jews in Israel: frequency and differential penetrance in ovarian cancer and in breast-ovarian cancer families. Am J Hum Genet 1997;60:1059-67. 